\title{
EFFECT OF SEWAGE NUTRIENTS ON ALGAL PRODUCTION, BIOMASS AND PIGMENTS IN TROPICAL TIDAL CREEKS
}

\author{
Burford, M.A. ${ }^{1}$, Revill, A.T. ${ }^{2}$, Smith, J. ${ }^{3}$, Clementson, L. ${ }^{2}$ \\ ${ }^{1}$ Australian Rivers Institute, Griffith University, Kessels Rd, Nathan QLD 4111, \\ Australia
}

2CSIRO Marine and Atmospheric Research, GPO Box 1538, Hobart, TAS 7001, Australia

${ }^{3}$ Geoscience Australia, GPO Box 378, Canberra, ACT 2601, Australia

Corresponding author:

Email: m.burford@griffith.edu.au

Keywords: phytoplankton, benthic microalgae, microphytobenthos, sewage markers, coprostanol, nitrogen 


\begin{abstract}
Microalgal blooms can result from anthropogenic nutrient loadings in coastal ecosystems. However, differentiating sources of nutrients remains a challenge. The response of phytoplankton and benthic microalgae (BMA) to nutrient loads was compared across tropical tidal creeks with and without secondary treated sewage. Primary productivity in the water column was limited by nitrogen availability in absence of sewage, with nitrogen saturation in the presence of sewage. Phytoplankton primary productivity rates and chlorophyll $a$ concentrations increased in response to sewage, and there was a greater response than for BMA. There was no change in algal pigment proportions within the phytoplankton or BMA communities. Concentrations of the sewage marker, coprostanol, were higher near sewage discharge points decreasing downstream, correlating with a decline in nutrient concentrations. This suggests that sewage was the main source of nitrogen and phosphorus. This study highlights the scale and type of response of algal communities to sewage nutrients.
\end{abstract}




\section{Introduction}

Anthropogenic nutrient loading of coastal waters is considered a major pollution problem globally (Vitousek et al., 1997; Howarth et al., 2002; Halpern et al., 2008). In heavily populated areas, sewage can contribute a substantial proportion of the nutrient inputs to coastal waters and is typically in forms conducive to stimulating primary production. Current projections are that the world's human population will continue to increase by 1 to $2 \% \mathrm{y}^{-1}$ (Cohen, 2003), thus the enrichment of coastal waters with nutrients will likely continue to escalate in years to come. The impact of anthropogenic nutrients on coastal waters is expected to be greater in the tropics than at higher latitudes (Downing et al., 1999; Halpern et al., 2008) since higher yearround water temperatures fuel higher rates of biogeochemical processes. Additionally, many developing countries are in the tropics, with large human populations and little or no treatment of sewage.

Coastal waters are typically nitrogen limited (Ryther and Dunstan, 1971). Therefore excessive nitrogen loads can stimulate excessive rates of primary production and a higher incidence of harmful algal blooms (Beman et al., 2005; Anderson et al., 2008; Bauman et al. 2010). This has flow-on effects to a range of biogeochemical processes and food webs (Mackenzie et al., 2002; Jennerjahn et al., 2004; Smith et al., 2012). The scale of the effect of sewage nutrient loadings is affected by the hydrodynamics of the receiving waters. Typically longer water residence times lead to more symptoms of eutrophication, due to less dilution and a resulting reduction in nutrient concentrations and phytoplankton biomass (e.g. Cloern, 2001).

Determining the response of aquatic systems to sewage inputs is often confounded by simultaneous and periodic inputs of non-point sources of nutrients, such as runoff from urban and agricultural land. Use of sewage-specific markers is one mechanism for differentiating the effect of sewage on ecosystem responses compared with other sources. Stable nitrogen isotopes in macroalgal bioassays have been used as a sewage marker in an Australian coastal bay (Costanzo et al., 2001, 2005). Additionally, the sterol, coprostanol $(5 \beta(\mathrm{H})$-cholestan-3 $\beta$-ol) has proven to be a successful indicator of 
faecal pollution, e.g. sewage, in many coastal environmental studies (e.g. Goodfellow et al., 1977, Leeming and Nichols, 1996; Peng et al., 2002).

A recent study by Smith et al. (2012) examined the effect of sewage nutrients on a range of biogeochemical processes in tidal creeks in a tropical harbour. They found that sediment nutrient fluxes increased and denitrification efficiency decreased in response to increased nutrient loads in creeks receiving sewage. The effect in these processes was greater than for a suite of other biogeochemical processes. Our study will compare these same creeks for the effect of sewage nutrients on algal measures. Specifically, we tested the hypothesis that sewage nutrients would differentially affect the phytoplankton and BMA communities, in terms of primary productivity, biomass and species composition.

\section{Methods}

Study Area

The study was undertaken in three tidal creeks in Darwin Harbour, northern Australia (Fig. 1). Two of the creeks received secondary-treated sewage inputs from sewage treatment plants (Myrmidon Creek (MC) in East Arm of Darwin Harbour, and Buffalo Creek (BC) in Shoal Bay). There was also one unnamed creek with no sewage inputs (herein referred to as Reference Creek, RC). Darwin Harbour is in the wet tropics, with a hot wet season (December to April) and a cooler dry season (May to November). The mean annual rainfall is $1719 \mathrm{~mm}$ with $64 \%$ of this falling between January and March, and mean monthly maximum water temperatures are similar throughout the year ranging from 30 to $33^{\circ} \mathrm{C}$ (McKinnon et al., 2006). The harbour is macro-tidal (maximum tidal range of $7.8 \mathrm{~m}$ ) and strong currents of up to $2 \mathrm{~m} \mathrm{~s}^{-1}$. The harbour is fringed by dense mangroves and during low tide, extensive intertidal mudflats are exposed.

Sediment and water column sampling was carried out at a range of sites in the three tidal creeks on the ebb tide. RC and MC have a similar geomorphology with predominantly straight channels, widening downstream (Fig. 1a, b). At low tide, intertidal mudflats, several metres wide, are exposed along the length of the creeks. 
$\mathrm{BC}$ consists of a long, narrow channel with large meander bends at the downstream end (Fig. 1c). A large intertidal sand bar across the mouth inhibits tidal movement.

RC was considered to be near-pristine, based on studies by Smith et al. (2012), and had a flushing time ranging between 0.3 and $0.6 \mathrm{~d}$ for spring and neap tides respectively. $\mathrm{MC}$ and $\mathrm{BC}$ received sewage effluent from sewage treatment plants (STP) which used waste stabilization ponds to remove organic matter and particulate nutrients. MC received $69 \mathrm{t}$ total nitrogen $(\mathrm{TN}) \mathrm{y}^{-1}$ and $18 \mathrm{t}$ total phosphorus $(\mathrm{TP}) \mathrm{y}^{-1}$ and during the study the treated sewage effluent was being discharged into the mangroves close to site MC1 (Fig. 1b). MC had flushing times of between 0.3 and 0.6 $\mathrm{d}$ for spring and neap tides respectively. $\mathrm{BC}$ received $79 \mathrm{t} \mathrm{TN} \mathrm{y}^{-1}$ and $43 \mathrm{t} \mathrm{TP}^{-1}$ and the treated sewage effluent was discharged into dense mangroves at the upstream end of the creek (Fig. 1c). The flushing times in BC near the sewage discharge site ranged between 1.6 and $4.8 \mathrm{~d}$ (Smith et al., 2012). The sewage discharge was gravity-fed, i.e. at high tide there was no flow, and at low tide there was maximum flow.

This study was conducted during 2007-8 over three sampling periods. Each sampling period lasted 5 to 6 days in between spring and neap tides during the 2-week tidal cycle. RC and MC were sampled in October 2007 and March 2008, and BC was sampled in December 2008.

\section{Water and sediment sampling}

Profiles of temperature, salinity, dissolved oxygen (DO) were measured at each site with a calibrated datalogger (YSI Sonde 6000XLM). Photosynthetically active radiation (PAR) was measured using a light meter with a $4 \pi$ quantum underwater sensor (LI-COR LI-192). Surface water samples were also collected. Total suspended solids (TSS) was determined by filtering water samples using pre-weighed membrane filters (0.45 $\mu \mathrm{m}$, Millipore), drying at $60^{\circ} \mathrm{C}$ and re-weighing. Samples for particulate stable nitrogen isotopes were collected by filtering water through pre-combusted GF/F glass fibre filters (Whatman). Filters were wrapped in pre-combusted aluminium foil and stored frozen.

For ammonium $\left(\mathrm{NH}_{4}{ }^{+}\right)$, nitrate plus nitrite $\left(\mathrm{NO}_{2}{ }^{-}+\mathrm{NO}_{3}{ }^{-}\right)$, phosphate $\left(\mathrm{PO}_{4}{ }^{3-}\right)$ and silicate $\left(\mathrm{SiO}_{4}\right)$ analyses, subsamples were filtered $(0.45 \mu \mathrm{m}$, Bonnet $)$ into tubes and 
frozen. Samples for chlorophyll $a(\operatorname{chl} a)$ and algal pigment analyses were collected by filtering water from just below the surface through GF/F filters (Whatman). The filters were stored in liquid nitrogen until analyzed.

For chl $a$ and algal pigments in the BMA, and coprostanol values, sediment cores (6 $\mathrm{cm}$ dia.) were collected at each site using a push corer. Surface sediment (to $1 \mathrm{~cm}$ depth) from each core was transferred into glass jars and homogenized. Samples for coprostanol were frozen, while samples for $\operatorname{chl} a$ and algal pigments were stored in liquid nitrogen until analyzed.

Porewater nutrients $\left(\mathrm{NH}_{4}{ }^{+}, \mathrm{NO}_{2}{ }^{-}+\mathrm{NO}_{3}{ }^{-}\right.$, or $\left.\mathrm{PO}_{4}{ }^{3-}\right)$ were determined from sediment cores $(7.3 \mathrm{~cm}$ dia.) collected from two sites in each creek using a push corer, and the corers sealed. Cores were stored in the dark at ambient temperature. Within a few hours of core retrieval, sediment from $1 \mathrm{~cm}$ depth intervals was extruded and subsampled for porewater extraction and porosity. Porewater was extracted by centrifugation $(18,000 \mathrm{~g}, 10 \mathrm{~min})$ and supernatant water was filtered $(0.45 \mu \mathrm{m}$ membrane filter) and frozen until analyzed. Porosity was determined on a subsample by weight difference between wet and dry sediment following freeze-drying.

Porewater nutrient concentrations per volume of wet sediment were calculated for each $2 \mathrm{~cm}$ depth interval in a core by accounting for the porosity. The porewater inventories for each nutrient were then calculated for a $10 \mathrm{~cm}$ sediment depth.

\section{Analytical Methods}

Dissolved inorganic nutrients $\left(\mathrm{NH}_{4}{ }^{+}, \mathrm{NO}_{2}{ }^{-}+\mathrm{NO}_{3}{ }^{-}, \mathrm{PO}_{4}{ }^{3-}\right.$ and $\left.\mathrm{SiO}_{4}\right)$ from the filtered surface water and porewater samples were analyzed by automated flow injection analysis (Lachat) using standard colorimetric methods. Chl $a$ and algal pigments were extracted from pre-weighed sediment and water column filters prior to analysis by high performance liquid chromatography following the procedures outlined in Cook et al. (2004) and Haese et al. (2007), respectively.

Sediment samples for sterol (coprostanol) analysis were extracted quantitatively by a modified one-phase dichloromethane-methanol method of Bligh and Dyer (1959). After phase separation, the lipids were recovered in the lower $\mathrm{CH}_{2} \mathrm{Cl}_{2}$ layer (solvents 
were removed in vacuo) and were made up to a known volume and stored sealed under nitrogen at $-20^{\circ} \mathrm{C}$. The total sterol fraction was obtained following alkaline saponification of an aliquot of the total lipids and were converted to their corresponding O-TMSi ethers by treatment with bis(trimethylsilyl)trifluoroacetamide $\left(100 \mu \mathrm{L}, 60^{\circ} \mathrm{C}, 60 \mathrm{~min}\right)$.

Gas chromatography (GC, Varian 3800) was run interfaced with chromatography software (Galaxy). The gas chromatograph was equipped with a $50 \mathrm{~m}$ x $0.32 \mathrm{~mm}$ i.d. cross-linked 5\% phenyl-methyl silicone (HP5) fused-silica capillary column; hydrogen was the carrier gas. Sterol fractions were analyzed using a flame ionisation detector (GC-FID), with 5 $\beta(\mathrm{H})$-cholan-24-ol (Chiron AS) as the internal standard. Peak identifications were based on retention times relative to authentic and laboratory standards and subsequent GC-mass spectrometry (MS) analysis.

Verification of the identity of individual sterols by GC-MS analyses was performed on a bench top mass spectrometer (Thermoquest GCQ-Plus) fitted with a direct capillary inlet and a split/splitless injector. Data were acquired in scan acquisition or selective ion monitoring and processed using software supplied with the instrument (Xcalibur). The nonpolar column (HP5) and operating conditions were similar to that described above for GC-FID analyses, but helium was used as the carrier gas.

\section{Water column and sediment primary productivity}

Water column primary production was measured using ${ }^{13} \mathrm{C}$-uptake incubations as per Burford et al. (2011). Triplicate water samples were incubated at 0, 5, 14, 25, 50 and $100 \%$ of surface light using shade bags of the appropriate light attenuation. ${ }^{13} \mathrm{C}$ sodium bicarbonate $\left({ }^{13} \mathrm{C} 99 \%\right.$, Cambridge Isotope Laboratories) was added to bottles to give a final enrichment of between 3 and $5 \%$ of the total bicarbonate concentration. The bottles were incubated with flowing water at ambient water temperature around midday for 2 to $3 \mathrm{~h}$. Known volumes of water from the bottles were filtered onto precombusted glass fibre (Whatman GF/F) filters, and the filters were frozen. 
Sediment cores ( $4.5 \mathrm{~cm}$ dia.) were collected at each site for measurement of ${ }^{13} \mathrm{C}$ uptake by BMA. Capped cores were transported with overlying water from the study site were used. Triplicate cores at each site were incubated at $100 \%$ of surface light.

${ }^{13} \mathrm{C}$-sodium bicarbonate was added to bottles to give a final enrichment of between 40 and $50 \%$ of the total bicarbonate concentration to the overlying water. Incubation conditions were the same as for the water column samples. The top $2 \mathrm{~cm}$ was sliced off each core and frozen until analyzed.

Filters from the ${ }^{13} \mathrm{C}$-uptake incubations were dried at $60^{\circ} \mathrm{C}$ for $24 \mathrm{~h}$ before being analyzed for ${ }^{13} \mathrm{C} /{ }^{12} \mathrm{C}$ ratio and $\%$ carbon on a MS (GV Isoprime). Areal primary productivity rates were determined using the methods of Burford et al. (2011). Sediment cores from benthic ${ }^{13} \mathrm{C}$-uptake incubations were processed in the same way following treatment with $6 \mathrm{~N}$ hydrochloric acid to remove carbonates. For BMA, only maximum primary productivity $\left(\mathrm{P}_{\max }\right)$ was calculated.

\section{Algal nutrient bioassays}

Surface water samples were also collected for algal nutrient bioassays using the methods of Burford et al. (2011). The assays involved pouring water into polycarbonate bottles with four treatments: control, nitrogen, phosphorus and nitrogen + phosphorus addition. There were three replicate bottles of each treatment. Ammonium chloride was added as the nitrogen treatment; potassium dihydrogen phosphate was added as the $\mathrm{P}$ treatment. The ambient $\mathrm{NH}_{4}{ }^{+}$concentration was assumed to be $1 \mu \mathrm{mol} \mathrm{L}{ }^{-1}$ and the ambient $\mathrm{PO}_{4}{ }^{3-}$ concentration was assumed to be 0.2 $\mu \mathrm{mol} \mathrm{L} \mathrm{L}^{-1}$, and nutrients were added at ten times the assumed ambient concentrations. Bottles were incubated with in a tub with flow-through water under 50\% shadecloth in ambient light for $24 \mathrm{~h}$. Bottles were then stored in the dark for at least $20 \mathrm{~min}$ prior to reading the photosynthetic yield response (Fv/Fm) using a PHYTOPAM (Heinz Walz GmbH, Effeltrich, Germany) (Ganf and Rea, 2007). Two readings were taken from each bottle.

\section{Statistical methods}

The algal data (water column and sediment chlorophyll $a$ and degradation pigments, sediment $\mathrm{P}_{\max }$, depth integrated primary productivity) violated the assumptions of normality. Data were therefore analyzed using a non-parametric Kruskall-Wallis test 
(SAS software) to compare creeks. For the algal nutrient bioassays, data were tested for normality, then treatments were compared with an unpaired t-test (SAS software). Algal marker pigments were compared between sampling occasions and creeks using Principal Component Analysis (PCA) graphs (PRIMER).

\section{Results}

Mean water temperatures across all three creeks ranged from 29.4 to $31.4^{\circ} \mathrm{C}$ across the study (Table 1). Mean salinities ranged from brackish (20.6) in the wet season to hypersaline (37.0) in the dry season. In BC, mean euphotic depths and DO concentrations were $1.6 \mathrm{~m}$ and $2.9 \mathrm{mg} \mathrm{L}^{-1}$ respectively, while in the other two creeks, mean euphotic depth was $4.6 \mathrm{~m}$, and mean DO concentration was $5.2 \mathrm{mg} \mathrm{L}^{-1}$. Mean $\mathrm{NH}_{4}{ }^{+}$concentrations in $\mathrm{MC}$ and $\mathrm{RC}$ were 0.24 and $0.63 \mu \mathrm{mol} \mathrm{L}{ }^{-1}$ respectively while in $\mathrm{BC}$, the mean concentration was $35.5 \mu \mathrm{mol} \mathrm{L}{ }^{-1}$ (Table 1). Similarly, mean $\mathrm{NO}_{2}{ }^{-}+$ $\mathrm{NO}_{3}{ }^{-}$concentrations in $\mathrm{MC}$ and $\mathrm{RC}$ were 0.17 and $0.45 \mu \mathrm{mol} \mathrm{L}{ }^{-1}$ respectively, while in $\mathrm{BC}$, the mean concentration was $14.1 \mu \mathrm{mol} \mathrm{\textrm {L } ^ { - 1 }}$. For $\mathrm{PO}_{4}{ }^{3-}$ concentrations in $\mathrm{MC}$ and $\mathrm{RC}$, mean values were 0.14 and $0.18 \mu \mathrm{mol} \mathrm{L} \mathrm{L}^{-1}$ respectively while in $\mathrm{BC}$, the mean concentration was $7.2 \mu \mathrm{mol} \mathrm{L}{ }^{-1}$. Mean $\mathrm{SiO}_{2}$ concentrations were 5.0, 18.5 and 38.4 $\mu \mathrm{mol} \mathrm{L}{ }^{-1}$ in $\mathrm{MC}, \mathrm{RC}$, and $\mathrm{BC}$ respectively.

Mean chl $a$ concentrations in the water column in MC and RC were 2.68 and $2.83 \mathrm{mg} \mathrm{m}^{-3}$ respectively and statistically lower $(P<0.005)$ than mean values in $\mathrm{BC}$ (90.0 $\mathrm{mg} \mathrm{m}^{-3}$, Fig. 2a, Table 2). There was also a statistically higher concentration of degradation pigments in $\mathrm{BC}$ compared with $\mathrm{MC}$ and $\mathrm{RC}$. The mean sediment chlorophyll concentrations in $\mathrm{MC}$ and $\mathrm{RC}$ were 2.74 and $2.76 \mu \mathrm{g} \mathrm{g}^{-1} \mathrm{ww}$ respectively with a high proportion of the total chlorophyll, i.e. $22-64 \%$, being degradation pigments (Fig. 2b). Sediment chlorophyll $a$ concentrations were statistically higher in $\mathrm{BC}$ than MC and RC (Table 2). The highest concentrations were at the sewage outfall site, i.e. $41.0 \mu \mathrm{g} \mathrm{g}^{-1} \mathrm{ww}$. There were statistically higher concentrations of degradation pigments in $\mathrm{BC}$.

The porewater $\mathrm{NH}_{4}, \mathrm{NO}_{2}{ }^{-}+\mathrm{NO}_{3}{ }^{-}$and $\mathrm{PO}_{4}$ inventories in the top $10 \mathrm{~cm}$ of sediment across MC and RC ranged from 0.78 to $4.67,0.05$ to 0.40 , and 0.02 to $0.07 \mathrm{mmol} \mathrm{m}^{-2}$ respectively (Table 1). In contrast, in $\mathrm{BC}$, porewater $\mathrm{NH}_{4}, \mathrm{NO}_{2}{ }^{-}+\mathrm{NO}_{3}{ }^{-}$and $\mathrm{PO}_{4}$ 
inventories in the top $10 \mathrm{~cm}$ of sediment were typically higher, ranging from 10.5 to $36.1,0.10$ to 0.69 and 0.12 to $2.71 \mathrm{mmol} \mathrm{m}^{-2}$ respectively.

Algal pigments in the water column in RC and MC in October 2007 were dominated by zeaxanthin (cyanobacterial marker) and fucoxanthin (diatom/golden brown flagellate marker) while in March 2008 they were only dominated by fucoxanthin (Table 3). BC was also dominated by fucoxanthin. The Principal Component Analysis (PCA) poorly separated the creeks with the exception of MC and RC in October 2007 (Fig. 3a). The first axis of the PC1, largely driven by fucoxanthin, explained $81 \%$ of the variation in the proportion of algal pigments across creeks and sites within creeks. In the sediment, fucoxanthin also dominated the pigments in $\mathrm{RC}$ and $\mathrm{MC}$ on both sampling occasions (Table 4). The first axis, PC1, again largely driven by fucoxanthin, explained $77 \%$ of the variation (Fig. 3b).

Depth-integrated primary productivity rates in the water column were statistically higher in Buffalo Creek than the other two creeks (Table 2, Fig. 4a). Mean rates were 10.09 and $11.62 \mathrm{mmol} \mathrm{m}^{-2} \mathrm{~d}^{-1}$ in MC and RC respectively, and $91.22 \mathrm{mmol} \mathrm{m}^{-2} \mathrm{~d}^{-1}$ in BC. However, maximum rates of primary productivity $\left(\mathrm{P}_{\max }\right)$ per unit chlorophyll $a$ were lower in $\mathrm{BC}$ than the other two creeks. Mean $\mathrm{P}_{\max }$ values in the BMA in RC, $\mathrm{MC}$, and $\mathrm{BC}$ were 1.58, 3.38 and $10.23 \mathrm{mmol} \mathrm{m}^{-2} \mathrm{~d}^{-1}$ respectively (Fig. 4b). There was a statistical difference between $\mathrm{RC}$ and $\mathrm{BC}$, and $\mathrm{BC}$ and $\mathrm{MC}$, but not between MC and RC (Table 2).

In $\mathrm{RC}$, the photosynthetic yield (Fv/Fm) of phytoplankton increased with nitrogen, and nitrogen plus phosphorus additions in nutrient bioassays at all sites and both sampling occasions (Fig. 5a). There was a response to nitrogen, and nitrogen plus phosphorus at the downstream sites at MC. However there was no yield response to nutrients at the site nearest the sewage outfall site in October 2007 while in March 2008, there was a response to nitrogen plus phosphorus. At Buffalo Creek, data was only available for one site nearest the outfall but there was no yield response to nitrogen and/or phosphorus. In the case of BMA bioassays, there was no yield response to nitrogen and/or phosphorus addition in any creek with the exception of a response to nitrogen plus phosphorus at RC1 in March 2008 (Fig. 5b). 
The sewage marker, coprostanol, was at a higher range of concentrations in $\mathrm{BC}$ compared with $\mathrm{RC}$ and $\mathrm{MC}$. It was highest in $\mathrm{BC}$ at the sewage outfall site, decreasing linearly with distance from the outfall (Fig. 6). In MC, concentrations were highest just upstream of the outfall site, decreasing to a background concentration by MC1. In $\mathrm{RC}$ concentrations were comparable with the downstream concentrations in MC.

Coprostanol concentrations were highly correlated with $\mathrm{NH}_{4}{ }^{+}$(Fig. 7a) and $\mathrm{PO}_{4}{ }^{3-}$ (Fig $7 b)$ concentrations in $\mathrm{BC}\left(\mathrm{R}^{2}=0.98\right.$ and 0.88 respectively). There was a weaker correlation between coprostanol and both $\mathrm{NO}_{2}{ }^{-}+\mathrm{NO}_{3}{ }^{-}$and chlorophyll $a\left(\mathrm{R}^{2}=0.53\right.$ and 0.35 respectively).

\section{Discussion}

This study found that higher nutrient concentrations in the tropical tidal creeks were the result of sewage loading. The tidal creek with sewage outfall discharging 79 and $43 \mathrm{t} \mathrm{TN}$ and TP $\mathrm{y}^{-1}$ (BC) had higher concentrations of a sewage marker, coprostanol, than a creek with no sewage inputs. These concentrations decreased linearly downstream. In contrast, a tidal creek receiving comparable loads of TN but with flushing rates 1.5 to 2 times higher (MC), only had higher coprostanol concentrations near the discharge site. Coprostanol has been used in a range of studies to track sewage in aquatic systems (e.g. McCalley et al., 1980, Leeming and Nichols 1996, Peng et al., 2002). Additionally, it has been proposed that linking algal blooms with coprostanol concentrations provides a means of differentiating nutrient source effects (Nichols et al., 1996).

Consistent with many other studies in coastal systems, our study found that nitrogen was a limiting nutrient for phytoplankton (Ryther and Dunstan, 1971). This was based on a positive photosynthetic yield response in short-term bioassays. This method has proven useful in identifying nutrient limitation in previous studies (Ganf and Rea 2007; Burford et al. 2011). A previous study in Darwin Harbour has also shown that the harbour as a whole was nitrogen limited (Burford et al., 2008). Therefore our results were as expected, i.e. nitrogen additions stimulated photosynthetic yield responses where sewage nitrogen was undetectable, while reverse was true at sites where sewage nitrogen was detectable. In contrast, BMA did not respond to nitrogen 
additions (or phosphorus), suggesting that nutrient reserves in the sediment were sufficient for growth and that other factors play a more important role.

Sewage nutrients increased primary productivity rates by phytoplankton, but not BMA. Phytoplankton productivity rates were high in the creek receiving the highest sewage loading and having the lowest tidal flushing (BC) compared with the harbour as a whole (Burford et al., 2008). Rates were comparable with those in eutrophied tidal creeks and estuaries in other areas of the world (Rivera-Monroy et al., 1998; Trott et al., 2004). The creek without sewage nutrients (RC) had primary productivity rates lower than both the harbour as a whole (Burford et al., 2008), and other tropical coastal waters (Ram et al., 2003; McKinnon et al., 2010). The creek with a similar flushing rate to $\mathrm{RC}$, but receiving sewage inputs (MC), also had similar rates of primary productivity to RC, even near the site of discharge. This demonstrates that tidal flushing plays an important role in minimizing the effect of algal growth.

Another study on the tidal creeks on our study found that sewage nutrients substantially increased sediment nutrient fluxes and decreased sediment denitrification efficiency (Smith et al., 2012). The combination of these two processes provided a feedback loop stimulating phytoplankton productivity, i.e. high phytoplankton productivity as a result of sewage nutrient inputs resulted in a higher detrital load on sediments, creating anoxia and nutrient remineralization which further stimulated phytoplankton growth. Reduced denitrification efficiency meant that nitrogen is conserved within the creek for a longer period, compounding the effects (Smith et al., 2012). The response to eutrophication measured in BC is consistent with broadly accepted models of eutrophication, e.g. Nixon (1995), Cloern (2001).

Despite the lack of increase in primary productivity in the BMA in response to sewage nutrients, chlorophyll $a$ concentrations were higher for both BMA and phytoplankton. However, this was only the case in $\mathrm{BC}$ which had the lowest tidal flushing rates. The contrasting effect of sewage nutrients on primary productivity versus chlorophyll $a$ concentrations may be because the high BMA biomass resulted in self shading, therefore reducing light availability for primary production. A study in an estuary in North Carolina, USA also showed an increase in BMA biomass in response to nitrogen and phosphorus, with a greater response to nitrogen loading 
(Piehler et al. 2010). Conversely, a study of primary productivity responses of BMA to sewage nutrients in eutrophic estuaries in Alabama, USA, which found that increased nutrient concentrations had little effect on primary production (Stutes et al. 2006).

Our study found no differences in phytoplankton group dominance, as measured by HPLC pigments, between creeks with and without sewage nutrients. Consistent with many tropical coastal waters around the world, diatom/golden brown flagellate pigments dominated with silicate concentrations sufficiently high to support diatom growth (e.g. Burford et al., 2005, Madhu et al., 2010). This contrasts with Hu et al. (2008) who found a historical increase in coprostanol concentrations in sedimentary records offshore from Hong Kong, as a result of human sewage inputs, which coincided with increased incidences of red tides, i.e. blooms of dinoflagellates, which contain the pigment, peridinin. An increase in red tides as a result of anthropogenic nutrients has been observed in a number of countries (Chen et al., 2010; Bauman et al., 2010; Glibert et al., 2012). Despite the lack of effect of sewage nutrients on phytoplankton dominance in our study, we found some evidence of a broader group of algal classes dominating in the BMA in the sewage creek (BC) compared with the other creeks.

Our study found that the scale of effect of sewage nutrients on algal measures appears to be affected by the water residence time in the tidal creeks. The two creeks received comparable nitrogen loads but the flushing rate in $\mathrm{MC}$ was 1.5 to 2 times higher in comparison to BC. There was localized detection of the sewage marker, coprostanol and changes in a range of algal measures, only near the point of discharge in the creek with the highest flushing rates (MC). In contrast, coprostanol and algal measures were higher throughout the creek with a longer residence time (BC). Other studies have found that longer water residence times lead to more symptoms of eutrophication (e.g. Cloern, 2001). However, our study provides a link between the scale of nutrient loading and water residence times, and the scale of algal response.

It is acknowledged that our sampling design only included one sampling trip to BC in the wet season, compared with two trips to the other creeks (one in the wet, one in the dry). A study by Smith et al. (2012) compared the rates of biogeochemical processes 
and water quality between the wet and dry seasons in these two creeks and found no statistical differences in most parameters, with salinity being a key exception. This suggests that the comparison of BC with the other two creeks, despite the differences in sampling design, is valid. Additionally, RC had higher nutrients and lower salinity than $\mathrm{MC}$ in the wet season trip, suggesting a greater catchment influence on water quality in RC. However, this did not result in statistically higher primary productivity or chlorophyll $a$ concentrations. The exception was a higher $\mathrm{P}_{\max }$ in the BMA.

In conclusion, this study differentiated sewage nutrient effects in a study of tidal creeks in the tropics. We also found that sewage nutrients stimulated algal growth but had a greater effect on phytoplankton than BMA, with the scale of the nutrient inputs and water dilution rates affecting the scale of response. In contrast, there was little evidence of sewage nutrients affecting algal group dominance. 


\section{Acknowledgements}

We wish to thank: the staff from the Aquatic Health Unit at the Northern Territory Department of Natural Resources, Environment, The Arts and Sport for assistance with boats and logistics; Emily Saeck, Dominic Valdez, Ralf Haese, Matt Carey and Craig Smith for assistance with field work and laboratory analyses; Ed Czobik (NSW DECC) and Frank Krikowa (UC) for nutrient analyses; Rene Diocares (GU) and Rebecca Esmay (CMAR) for isotope analysis; Rhys Leeming (CMAR) helped with coprostanol analysis; and Peter Rothlisberg, Barbara Robson and Emmanuel Grojean provided useful comments on the manuscript. This project was conducted as part of the Tropical Rivers and Coastal Knowledge (TRaCK) program. TRaCK received major funding for its research through the Australian Government's Commonwealth Environment Research Facilities initiative; the Australian Government's Raising National Water Standards Program; Land and Water Australia; the Fisheries Research and Development Corporation and the Queensland Government's Smart State Innovation Fund. This paper is published with the permission of the CEO, Geoscience Australia. 


\section{References}

Anderson, D.M., Burkholder, J.M., Cochlan, W.P., Glibert, P.M., Gobler, C.J., Heil, C.A., Kudela, R.M., Parsons, M.L. Rensel, J.E.J., Townsend, D.W., Trainer, V.L., Vargo, G.A. 2008. Harmful algal blooms and eutrophication: Examining linkages from selected coastal regions of the United States. Harmful Algae 8: $39-53$.

Bauman, A.G., Burt, J.A., Feary, D.A., Marquis, E., Usseglio, P. 2010. Tropical harmful algal blooms: An emerging threat to coral reef communities? Marine Pollution Bulletin 60: 2117-2122.

Beman, J.M., Arrigo, K.R., Matson, P.A., 2005. Agricultural runoff fuels large phytoplankton blooms in vulnerable areas of the ocean. Nature 434: 211-214.

Bligh, E.G., Dyer, W.J. 1959. A rapid method of total lipid extraction and purification. Canadian Journal of Biochemistry and Physiology 37: 911-917.

Burford, M.A., Rothlisberg, P.C., Wang, Y. 1995. Spatial and temporal distribution of tropical phytoplankton species and biomass in Albatross Bay, Gulf of Carpentaria, Australia. Marine Ecology Progress Series 118: 255-266.

Burford, M.A., Alongi, D.M., McKinnon, A.D., Trott, L.J. 2008. Primary production and nutrients in a tropical macrotidal estuary, Darwin Harbour, Australia. Estuarine, Coastal and Shelf Science, 79: 440-448.

Burford, M. A., Revill, A.T. Palmer, D.W. Clementson, L., Robson, B.J., Webster, I.T. 2011. River regulation alters drivers of primary productivity along a tropical river-estuary system. Marine and Freshwater Research, 62: 141-151.

Chen, B., Xu, Z., Xhou, Q., Chen, C.P., Gao, Y.H., Yang, S.Y., Ji, W.D. 2010. Longterm changes of phytoplankton community in Xiagu waters of Xiamen, China. Acta Oceanologica Sinica 29: 104-114.

Cloern, J.E. 2001. Our evolving conceptual model of the coastal eutrophication problem. Marine Ecology Progress Series 210: 233-253.

Cohen, J.E. 2003. The next half century. Science 302: 1172-1175. 
Cook, P.L.M., Revill, A.T., Clementson, L.A., Volkman, J.K. 2004. Carbon and nitrogen cycling on intertidal mudflats of a temperate Australian estuary III. Sources of organic matter. Marine Ecology Progress Series 280: 55-72

Costanzo, S.D., O’Donohue, S.D., Dennison, W.C., Loneragan, N.R., Thomas, M. 2001. A new approach for detecting and mapping sewage impacts. Marine Pollution Bulletin 42: 149-156.

Costanzo, S.D., Udy, J., Longstaff, B., Jones, A. 2005. Using nitrogen stable isotope ratios (delta $\mathrm{N}-15$ ) of macroalgae to determine the effectiveness of sewage upgrades: changes in the extent of sewage plumes over four years in Moreton Bay, Australia. Marine Pollution Bulletin 515: 212-217.

Downing, J.A., McClain, M., Twilley, R., Melack, J.M., Elser, J., Rabalais, N.N., Lewis, W.M., Turner, R.E., Corredor, J., Soto, D., Yanez-Arancibia, A., Kopaska, J.A., Howarth, R.W. 1999. The impact of accelerating land-use change on the $\mathrm{N}$-cycle of tropical aquatic ecosystems: current conditions and projected changes. Biogeochemistry 46: 109-148.

Ganf, G.G., Rea N. 2007. Potential for algal blooms in tropical rivers of the Northern Territory, Australia. Marine and Freshwater Research 58: 315-326.

Glibert, P.M., Burkholder, J.M., Kana, K.M. 2012. Recent insights about the relationships between nutrient availability, forms and stoichiometry, and the distribution, ecophysiology, and food web effects of pelagic and benthic Prorocentrum species. Harmful Algae 14: 231-259.

Haese, R.R., Murray, E.J., Smith, C.S., Smith, J., Clementson, L., Heggie, D.T. 2007. Diatoms control nutrient cycles in a temperate, wave-dominated estuary (southeast Australia). Limnology and Oceanography 52: 2686-2711.

Halpern, B.S., Walbridge, S., Selkoe, K.A., Kappel, C.V., Micheli, F., Kappel, C.V., Micheli, F., D’Agrosa, C., Bruno, J.F., Casey, K.S., Ebert, C., Fox, H.E., Fujita, R., Heinemann, D., Lenihan, H.S., Madin, E.M.P., Perry, M.T., Selig, E.R., Spalding, M., Steneck, R., Watson, R. 2008. A global map of human impact on marine ecosystems. Science 319: 948-952. 
Howarth, R., Sharpley, A., Walker, D. 2002. Sources of nutrient pollution to coastal waters in the United States: implications for achieving coastal water quality goals. Estuaries and Coasts 25: 656-676

Hu, J., Zhang, G., Kechang, L., Peng, P., Chivas, A.R. 2008. Increased eutrophication offshore Hong Kong, China during the past 75 years: Evidence from highresolution sedimentary records. Marine Chemistry 110, 7-17.

Jennerjahn, T.C., Ittekkot, V., Klopper, S., Adi, S., Purwo Nugroho, S., Sudiana, N., Yusmal, A., Prihartanto, Gaye-Haake, B. 2004. Biogeochemistry of a tropical river affected by human activities in its catchment: Brantas River estuary and coastal waters of Madura Strait, Java, Indonesia. Estuarine, Coastal and Shelf Science 60: 503-514

Leeming, R., Nichols, P.D. 1996. Concentrations of coprostanol that correspond to existing bacterial indicator guideline limits. Water Research 30: 2997-3006.

Madhu, N.V., Balachandran, K.K., Martin, G.D., Jyothibabu, R., Thottathil, S.D., Maheswari Nair, T. Joseph, K.K. Kusum. 2010. Short-term variability in water quality and its implications for phytoplankton production in a tropical estuary (Cochin backwaters - India). Environmental Monitoring and Assessment 170: 287-300.

Mackenzie, F.T., Ver, L.M., Lerman, A. 2002. Century-scale nitrogen and phosphorus controls of the carbon cycle. Chemical Geology 190: 13-32

McCalley, C.V., Cooke, M., Nickless, G. 1980. Coprostanol in Severn estuary sediments. Bulletin of Environmental Contaminants and Toxicology 25: 374381.

McKinnon, A.D., Smit, N., Townsend, S., Duggan, S. 2006. Darwin Harbour: Water quality and ecosystem structure in a tropical harbour in the early stages of development. In: E. Wolanski (Editor), The Environment in Asia Pacific Harbours. Springer, Dordrecht, pp. 433-459.

McKinnon, A.D., Trott, L.A., Brinkman, R., Duggan, S., Castine, S., O’Leary, R.A., Alongi, D.M. 2010. Seacage aquaculture in a World Heritage Area: the environmental footprint of a Barramundi farm in tropical Australia. Marine Pollution Bulletin 60: 1489-1501 
Nichols, P.D., Leeming, R., Rayner, M.S., Latham. V. 1996. Use of capillary gas chromatography for measuring fecal-derived sterols. Application to stormewater, the sea-surface microlayer, beach greases, regional studies, and distinguishing algal blooms and human and non-human sources of sewage pollution. Journal of Chromatography A 733: 497-509.

Nixon, S.W. 1995. Coastal marine eutrophication: a definition, social causes, and future concerns. Ophelia 41: 199-219

Peng, X., Zhang, G., Mai, B., Min, Y., Wang, Z. 2002. Spatial and temporal trend of sewage pollution indicated by coprostanol in Macao Estuary, southern China. Marine Pollution Bulletin 45: 295-299.

Piehler, M.F., Currin, C.A., Hall, N.S. 2010. Estuarine intertidal sandflat benthic microalgal reponses to in situ and mesocosm nitrogen additions. Journal of experimental Marine Biology and Ecology 390: 99-105.

Ram, A.S.P., Nair, S., Chandramohan, D. 2003. Seasonal shift in net ecosystem production in a tropical estuary. Limnology and Oceanography 48: 1601-1607.

Rivera-Monroy, V., Madden, C., Day, J., Twilley, R., Vera-Herrera, F., AlvarezGuillén, H. 1998. Seasonal coupling of a tropical mangrove forest and an estuarine water column: enhancement of aquatic primary productivity. Hydrobiologia 379: 41-53

Ryther, J.H., Dunstan, W.M. 1971. Nitrogen, P, and eutrophication in the coastal marine environment. Science 171: 1008-1013.

Smith, J., Burford, M.A., Revill, A.T., Haese, R.R., Fortune, J. 2012. Effect of nutrient loading on biogeochemical processes in tropical tidal creeks. Biogeochemistry, 108: 359- 380.

Stutes, A.L., Cebrian, J., Corcoran, A.A. 2006. Effects of nutrient enrichment and shading on sediment primary production and metabolism in eutrophic estuaries. Marine Ecology Progress Series 312: 29-43.

Trott, L.A., McKinnon, A.D., Alongi, D.M., Davidson, A., Burford, M.A. 2004. Carbon and nitrogen processes in a mangrove creek receiving shrimp farm effluent. Estuarine, Coastal and Shelf Science, 59: 197-207.

Vitousek, P.M. 1997. Human domination of Earth's ecosystems. Science 278: 21. 


\section{Figure Captions}

Figure 1: Map of Darwin Harbour, Australia showing the sites of the (a) Reference Creek, (b) Myrmidon Creek, (c) Buffalo Creek in three tidal creeks in the study, and maps showing expanded details of the creeks including sampling sites. STP = sewage treatment plant.

Figure 2: Chl $a$ and chlorophyll degradation product concentrations in the (a) water column $\left(\mathrm{mg} \mathrm{m}^{-3}\right)$ and (b) sediment $\left(\mu \mathrm{g} \mathrm{g}^{-1} \mathrm{ww}\right)$ in sites in the three creeks for the three sampling occasions. Black $=$ chlorophyll $a$ in Myrmidon $\mathrm{Ck}$, dotted $=$ degradation products in Myrmidon Ck, grey $=$ chlorophyll $a$ in Reference $\mathrm{Ck}$, vertical stripes $=$ degradation products in Myrmidon $\mathrm{Ck}$, white $=$ chlorophyll $a$ in Buffalo $\mathrm{Ck}$, oblique stripes $=$ degradation products in Buffalo $\mathrm{Ck}$.

Figure 3: PCA plot showing algal pigment ratios in the (a) water column and (b) sediment at sites in each creek on each sampling occasion.

Figure 4: Primary productivity in the (a) water column (depth-integrated productivity, mmol C m$\left.{ }^{-2} \mathrm{~d}^{-1}\right)$ and (b) sediment $\left(\mathrm{P}_{\max }, \mathrm{mmol} \mathrm{C} \mathrm{m}^{-2} \mathrm{~d}^{-1}\right)$ at the sites in the three creeks on three sampling occasions. bd = below detection.

Figure 5: Photosynthetic yield (Fv/Fm) to nutrient addition compared with a control in the (a) water column and (b) sediment at sites in the three creeks on three sampling occasions. A, B and $\mathrm{C}$ refer to statistical differences $(P<0.05)$ between treatments. $\mathrm{MC} 1 \mathrm{a}$ and $\mathrm{MC} 1 \mathrm{~b}$ refers to experiments conducted at this site on two consecutive days.

Figure 6: Coprostanol concentrations $\left(\mu \mathrm{g} \mathrm{g}^{-1}\right)$ in the sediment at sites down each creek RC and MC were sampled in October 2007 and BC in December 2008.

Figure 7: Coprostanol concentrations versus (a) $\mathrm{NH}_{4}{ }^{+}$, and (b) $\mathrm{PO}_{4}{ }^{3-}$ concentrations across multiple sites and creeks. 
Table 1: Mean $( \pm \mathrm{SD})$ physico-chemical parameters in the water column, and porewater nutrient inventories in three tidal creeks in Darwin Harbour during the sampling periods. Adapted from Smith et al. (2012).

\begin{tabular}{|c|c|c|c|c|c|}
\hline & \multicolumn{2}{|c|}{ Myrmidon Creek } & \multicolumn{2}{|c|}{ Reference Creek } & Buffalo Creek \\
\hline Variable & Oct-07 & Mar-08 & Oct-07 & Mar-08 & Dec-08 \\
\hline Water temperature $\left({ }^{\circ} \mathrm{C}\right)$ & $30.3(0.8)$ & $29.9(0.7)$ & $31.4(0.5)$ & $29.4(0.6)$ & $30.7(2.0)$ \\
\hline Salinity & $36.5(0.4)$ & $29.3(1.3)$ & $37.0(0.3)$ & $22.5(3.5)$ & $20.6(10.0)$ \\
\hline Total suspended solids $\left(\mathrm{mg} \mathrm{L}^{-1}\right)$ & $15.8(5.6)$ & $28.3(5.5)$ & $17.1(3.5)$ & $12.3(4.6)$ & $97.7(131.3)$ \\
\hline DO conc. $\left(\mathrm{mg} \mathrm{L}^{-1}\right)$ & $5.2(0.5)$ & $5.5(0.5)$ & $5.1(0.6)$ & $5.2(0.6)$ & $2.9(1.8)$ \\
\hline Euphotic depth (m) & $5.9(1.9)$ & $3.8(0.3)$ & $5.2(2.1)$ & $3.7(1.3)$ & $1.6(0.8)$ \\
\hline $\mathrm{NH}_{4}^{+}\left(\mu \mathrm{mol} \mathrm{L}{ }^{-1}\right)$ & $0.15(0.17)$ & $0.33(0.11)$ & $0.15(0.09)$ & $1.11(0.36)$ & $35.5(24.2)$ \\
\hline $\mathrm{NO}_{2}^{-}+\mathrm{NO}_{3}^{-}\left(\mu \mathrm{mol} \mathrm{L}^{-1}\right)$ & $0.07(0.06)$ & $0.27(0.21)$ & $0.13(0.13)$ & $0.77(0.40)$ & $14.1(10.2)$ \\
\hline $\mathrm{PO}_{4}^{3}\left(\mu \mathrm{mol} \mathrm{L}^{-1}\right)$ & $0.14(0.13)$ & $0.13(0.03)$ & $0.21(0.07)$ & $0.15(0.02)$ & $7.2(4.9)$ \\
\hline $\mathrm{SiO}_{4}\left(\mu \mathrm{mol} \mathrm{L}^{-1}\right)$ & $4.4(3.8)$ & $5.7(0.8)$ & $10.6(4.4)$ & $26.4(2.3)$ & $38.4(21.4)$ \\
\hline Porewater $\mathrm{NH}_{4}{ }^{+}$inventory $\left(\mathrm{mmol} \mathrm{m}^{-2}\right)$ & $0.78-3.92$ & $4.30-4.67$ & $2.55-3.00$ & $1.74-3.09$ & $10.5-36.1$ \\
\hline Porewater $\mathrm{NO}_{2}^{-}+\mathrm{NO}_{3}^{-}$inventory $\left(\mathrm{mmol} \mathrm{m}^{-2}\right)$ & $0.06-0.10$ & $0.13-0.40$ & $0.05-0.05$ & $0.07-0.11$ & $0.10-0.69$ \\
\hline Porewater $\mathrm{PO}_{4}{ }^{3-}$ inventory $\left(\mathrm{mmol} \mathrm{m}^{-2}\right)$ & $0.04-0.05$ & $0.03-0.07$ & $0.02-0.02$ & $0.02-0.04$ & $0.12-2.71$ \\
\hline
\end{tabular}


Table 2: $P$ values from comparisons of algal variables in the water column and sediment in three creeks: Myrmidon (MC), Buffalo (BC) and Reference (RC) using a non-parametric one-way ANOVA. Statistically significant $p$-values in bold. w/c = water column.

\begin{tabular}{|c|c|c|c|c|}
\hline $\begin{array}{l}\text { Water column } \\
\text { or Sediment }\end{array}$ & Variable & $\begin{array}{l}\text { RC vs. MC } \\
P \text { value }\end{array}$ & $\begin{array}{l}\text { RC vs. BC } \\
P \text { value }\end{array}$ & $\begin{array}{l}\text { MC vs. BC } \\
P \text { value }\end{array}$ \\
\hline \multirow[t]{4}{*}{$\mathrm{w} / \mathrm{c}$} & Chl $a$ & 0.796 & 0.006 & 0.003 \\
\hline & $\begin{array}{l}\text { Algal degradation } \\
\text { pigments }\end{array}$ & 0.052 & 0.003 & 0.003 \\
\hline & $\begin{array}{l}\text { Depth integrated } \\
\text { prim. prod. }\end{array}$ & 0.873 & 0.020 & 0.020 \\
\hline & $\mathrm{P}_{\max } / \operatorname{chl} a$ & 0.200 & 0.020 & 0.020 \\
\hline \multirow[t]{3}{*}{ Sediment } & Chl $a$ & 0.897 & 0.006 & 0.003 \\
\hline & $\begin{array}{l}\text { BMA degradation } \\
\text { pigments }\end{array}$ & 0.519 & 0.006 & 0.003 \\
\hline & BMA $_{\max }$ & 0.027 & 0.015 & 0.197 \\
\hline
\end{tabular}


Table 3: Mean (SD) algal pigment ratios normalized to chl $a$ in the water column in three creeks in Darwin Harbour. Fuco = fucoxanthin, Zea = zeaxanthin, Perid = peridinin, Allo = alloxanthin, Lut = lutein, Chl b = chlorophyll b, Pras = prasinoxanthin, Hex-fuco = 19’ hexanoyloxyfucoxanthin, bd = below detection limit.

\begin{tabular}{|c|c|c|c|c|c|c|c|c|}
\hline Creek & Fuco & Zea & Perid & Allo & Lut & Chl b & Pras & Hex-fuco \\
\hline $\begin{array}{c}\mathrm{MC} \\
\text { Oct'07 }\end{array}$ & $0.137(0.024)$ & $0.190(0.075)$ & $0.048(0.045)$ & $0.049(0.045)$ & $0.054(0.013)$ & $0.054(0.013)$ & $0.009(0.005)$ & $0.003(0.005)$ \\
\hline $\begin{array}{c}\text { RC } \\
\text { Oct-07 }\end{array}$ & $0.208(0.092)$ & $0.106(0.054)$ & $0.099(0.131)$ & $0.015(0.007)$ & $0.003(0.001)$ & $0.031(0.012)$ & $0.009(0.004)$ & $0.020(0.009)$ \\
\hline $\begin{array}{c}\text { MC } \\
\text { Mar'08 }\end{array}$ & $0.401(0.032)$ & $0.031(0.002)$ & $0.010(0.007)$ & $0.012(0.002)$ & bd & $0.028(0.006)$ & bd & $0.004(0.002)$ \\
\hline $\begin{array}{c}\text { RC } \\
\text { Mar'08 }\end{array}$ & $0.359(0.002)$ & $0.011(0.002)$ & $0.042(0.016)$ & $0.014(0.016)$ & bd & $0.022(0.007)$ & bd & bd \\
\hline $\begin{array}{c}\text { BC } \\
\text { Dec'08 }\end{array}$ & $0.463(0.259)$ & $0.020(0.013)$ & bd & bd & $0.039(0.032)$ & $0.040(0.029)$ & bd & bd \\
\hline
\end{tabular}


Table 4: Mean (SD) BMA pigment ratios normalized to chl $a$ in three creeks in Darwin Harbour. Fuco $=$ fucoxanthin, Zea $=$ zeaxanthin, Lut $=$ lutein, $\mathrm{Chl} b=$ chlorophyll b, But = 19'-butanoyloxyfucoxanthin, Allo = alloxanthin, Hex-fuco = 19'-hexanoyloxyfucoxanthin, bd = below detection limit.

\begin{tabular}{|c|c|c|c|c|c|c|c|}
\hline Creek & Fuco & Zea & Lut & Chl b & But & Allo & Hex \\
\hline $\begin{array}{c}\text { MC } \\
\text { Oct'07 }\end{array}$ & $0.245(0.025)$ & $0.079(0.020)$ & $0.039(0.026)$ & bd & $0.015(0.006)$ & bd & bd \\
\hline $\begin{array}{c}\text { RC } \\
\text { Oct'07 }\end{array}$ & $0.290(0.036)$ & $0.095(0.028)$ & $0.011(0.009)$ & bd & $0.037(0.023)$ & bd & bd \\
\hline $\begin{array}{c}\text { MC } \\
\text { Mar'08 }\end{array}$ & $0.249(0.051)$ & $0.076(0.016)$ & $0.032(0.016)$ & $0.057(0.034)$ & bd & $0.013(0.003)$ & bd \\
\hline $\begin{array}{c}\text { RC } \\
\text { Mar'08 }\end{array}$ & $0.367(0.021)$ & $0.043(0.011)$ & $0.015(0.006)$ & $0.036(0.009)$ & bd & $0.014(0.003)$ & bd \\
\hline $\begin{array}{c}\text { BC } \\
\text { Dec'08 }\end{array}$ & $0.152(0.071)$ & $0.068(0.032)$ & $0.068(0.038)$ & $0.113(0.066)$ & $0.014(0.008)$ & bd & b.009 (0.006) \\
\hline
\end{tabular}


Figure 1
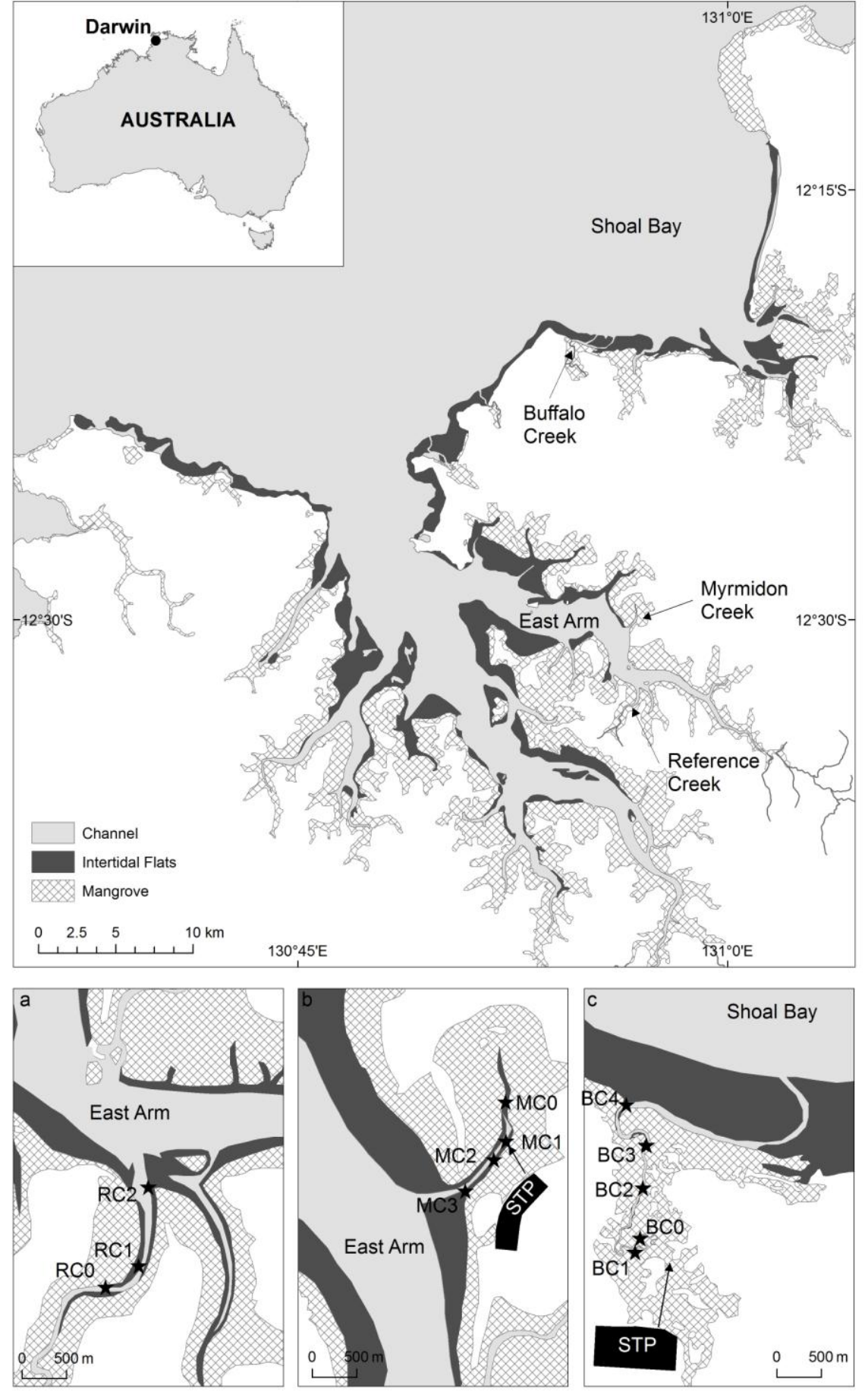
Figure 2
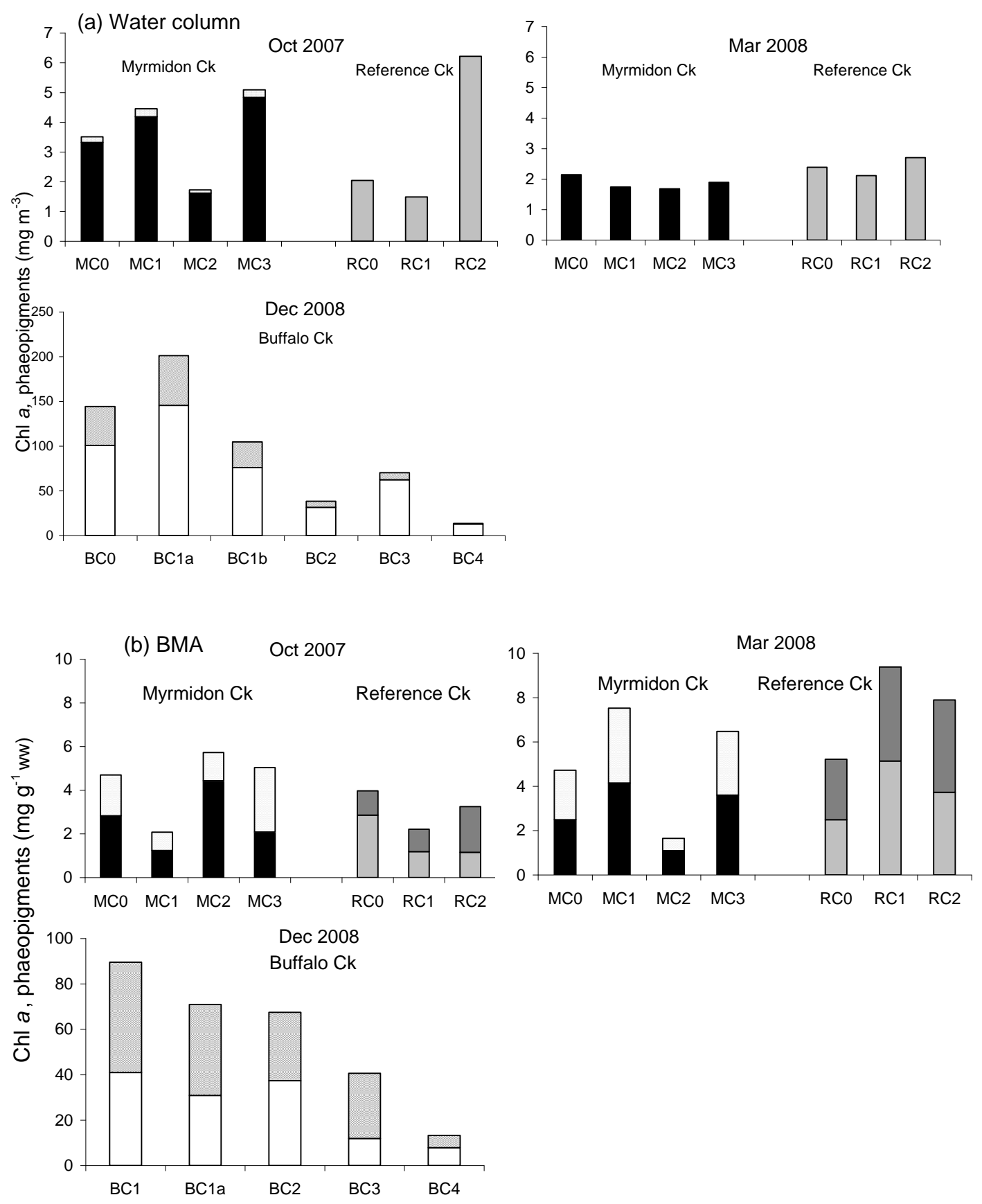
Figure 3

a)

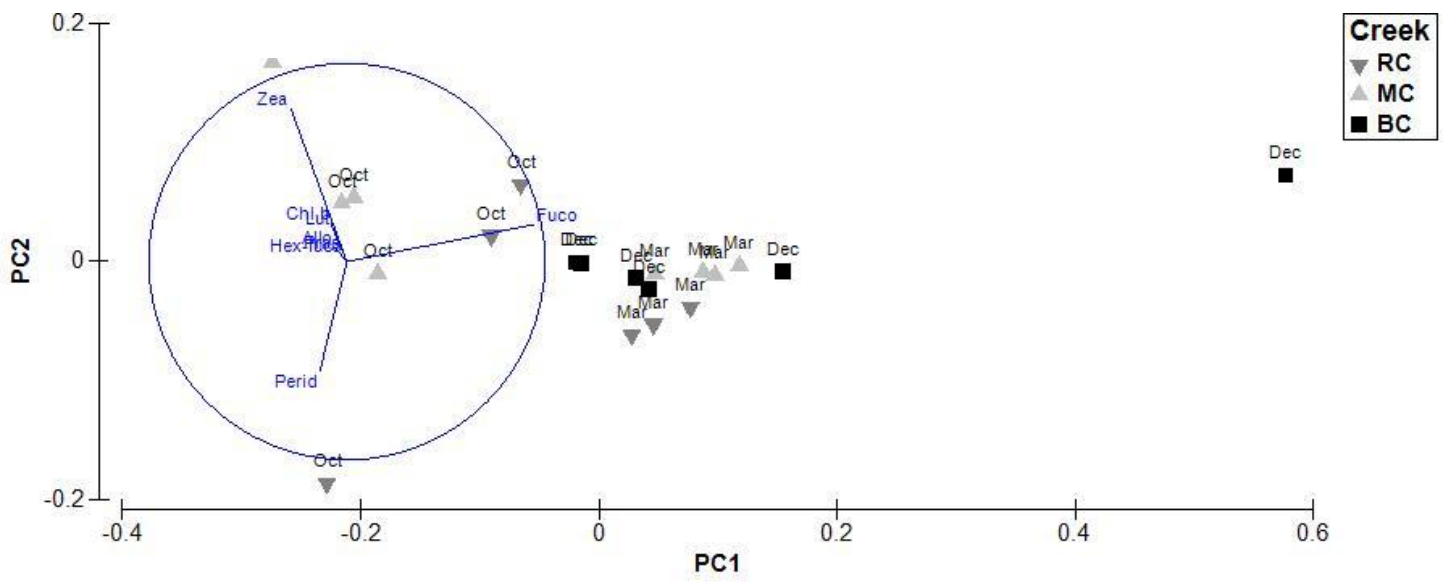

b)

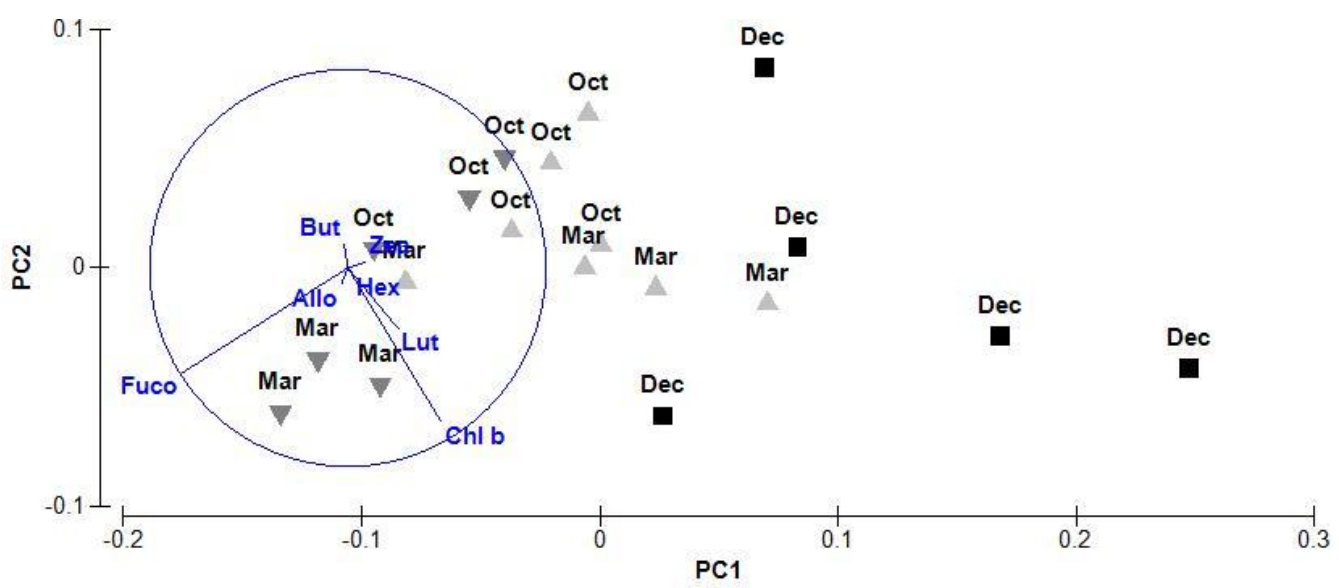


Figure 4
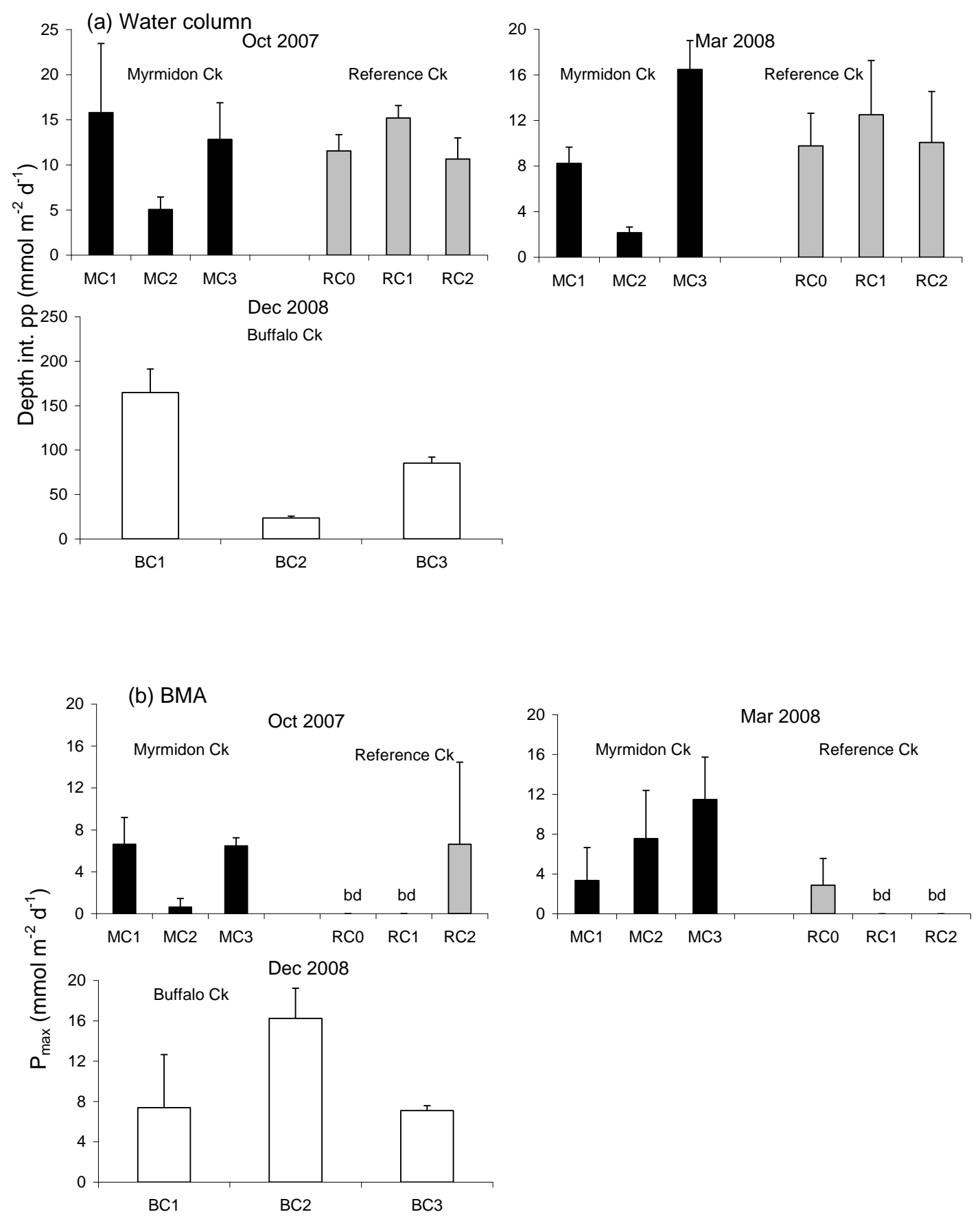
Figure 5
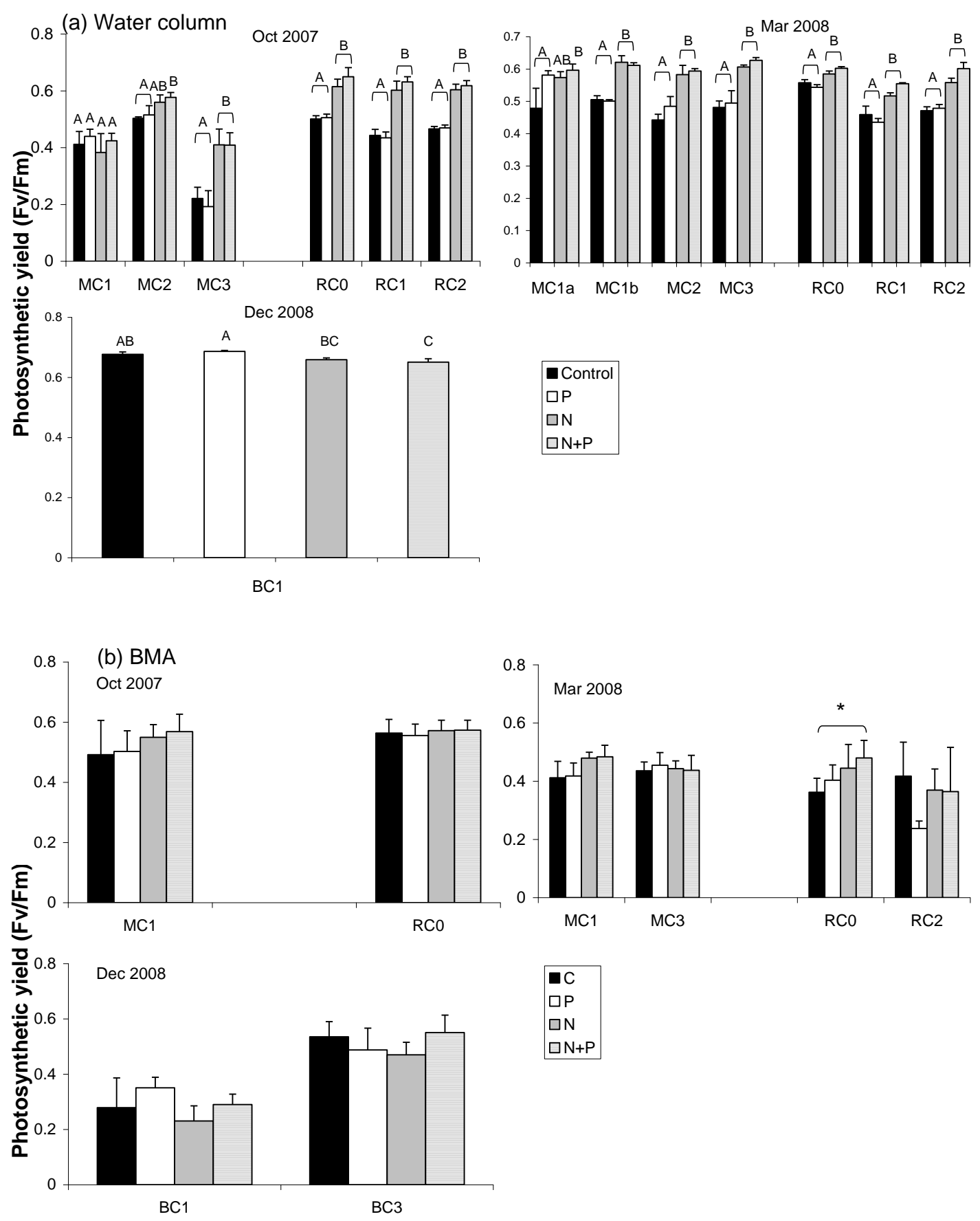
Figure 6
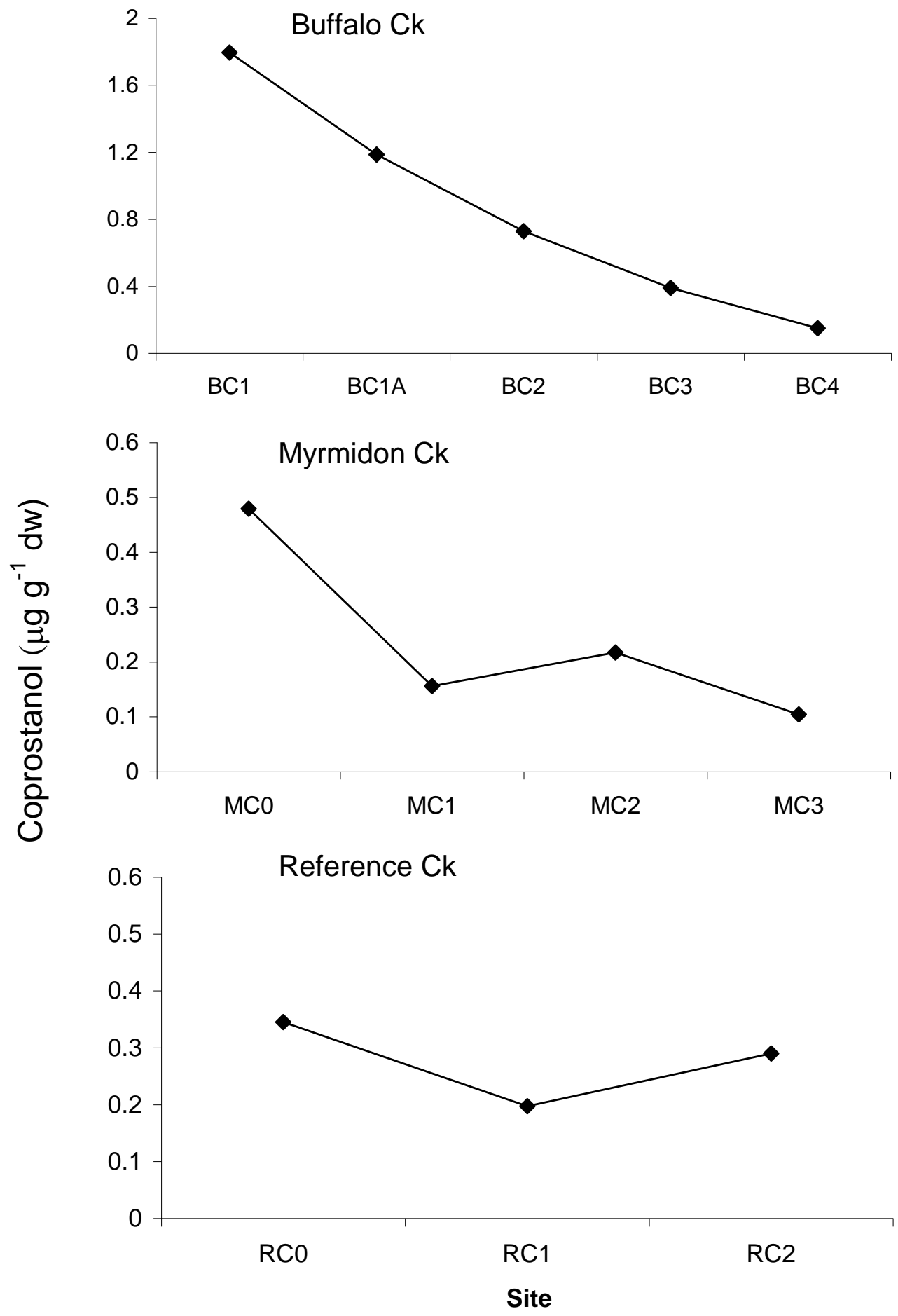

Downstream 
Figure 7

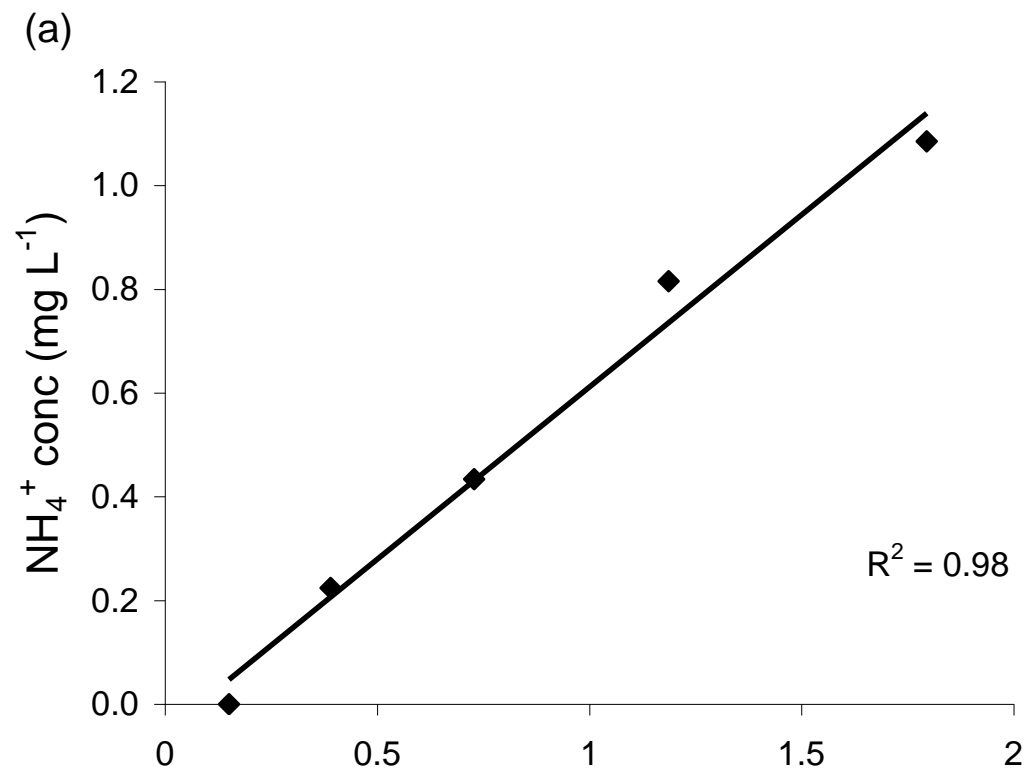

(b)

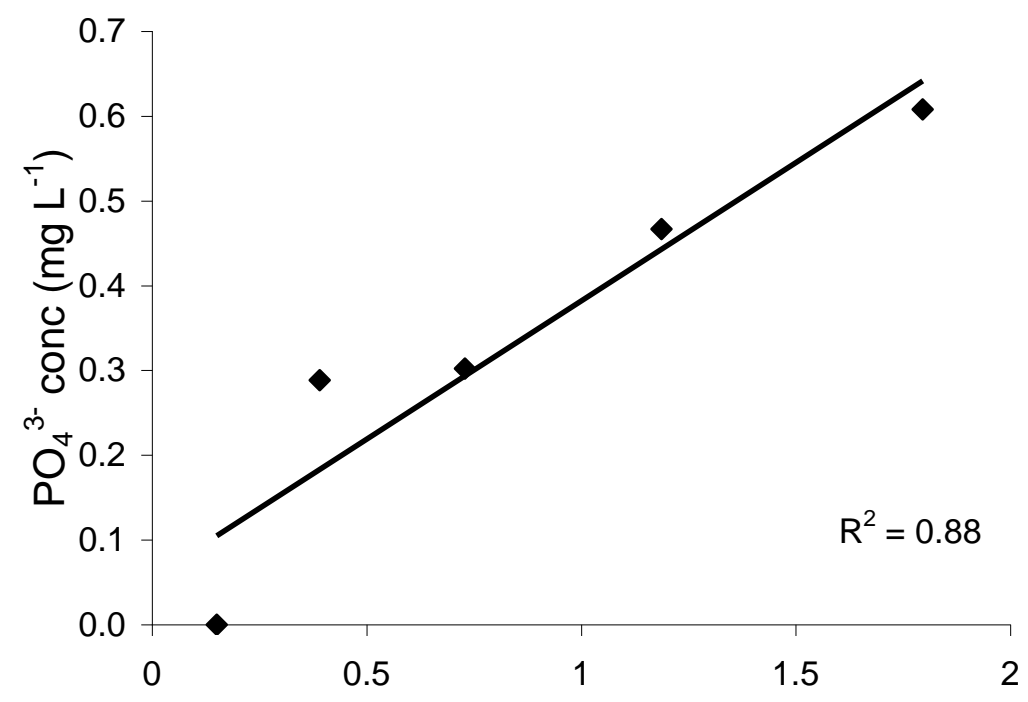

Coprostanol $\left(\mu \mathrm{g} \mathrm{g}^{-1} \mathrm{dw}\right)$ 